\title{
Specificity of the proteus antibody response in rheumatoid arthritis
}

\author{
C M Deighton, J Gray, A J Bint, D J Walker
}

\begin{abstract}
Antibodies to proteus were determined by indirect immunofluorescence in 146 serum samples from patients with rheumatoid arthritis (RA). An autoantibody screen was performed in the same samples and in 52 of these antibody titres to the viruses influenza $A$, adenovirus, rubella, and parvovirus were determined. There was no significant correlation between proteus antibodies and any of the other antibodies tested. Dividing the samples into those from patients with active $(C$ reactive protein $>10 \mathrm{mg} / \mathrm{l}$ ) and inactive $R A$ showed that the only antibodies to be significantly increased in active $R A$ were the proteus antibodies. These observations suggest that the proteus antibody response in RA is specific.
\end{abstract}

(Ann Rheum Dis 1992; 51: 1206-1207)

We are one of three independent groups to describe an increase of proteus antibodies in the active phases of rheumatoid arthritis (RA). ${ }^{1-3}$ Ebringer and coworkers have shown that other commonly occurring bacteria do not show the same phenomenon in RA. ${ }^{5}$ Rogers et al showed that proteus antibodies were not increased in other chronic inflammatory diseases to the extent seen in RA. ${ }^{2}$ The possibility remains, however, that this increase in antibody levels is simply a reflection of the polyclonal gammopathy in the acute phase response, and may be a property reflected by other antibodies. Furthermore the antibodies may be cross reactive with a number of other autoantibodies and antibodies directed against common pathogens. Do such antibodies correlate with proteus antibody titres, and do these antibodies show an increase during active phases of the disease? We have addressed these possibilities by determining autoantibodies and antibodies to viruses in the same serum samples used for

Department of Rheumatology, Royal Victoria Infirmary, Newcastle upon Tyne, NE1 4LP

United Kingdom

C M Deighton

D J Walker

Department of

Microbiology,

Royal Victoria Infirmary,

Newcastle upon Tyne,

NE1 4LP,

United Kingdom

J Gray

A J Bint

Correspondence to:

Dr Deighton.

Accepted for publication

15 July 1992 the determination of levels of proteus antibodies.

\section{Subjects and methods}

The group of subjects from whom stored serum samples were used has been described in detail elsewhere. ${ }^{6}$ Briefly, classical and definite $\mathbf{R A}^{7}$ probands were selected from outpatient clinics on the basis of same sexed geographically accessible siblings being available for genetic epidemiology studies. The same sample of serum was divided for the determination of proteus antibodies using an indirect immunofluorescence technique (no fluorescence at serum dilutions of $1 / 10=0$, fluorescence at
$1 / 10=1,1 / 20=2$; see Deighton et al ${ }^{3}$ for details), $\mathrm{C}$ reactive protein (Emit, Syva), antibodies directed against parvovirus, influenza $A$, adenovirus, and rubella, ${ }^{8}$ and an autoantibody screen. The following autoantibodies were determined: rheumatoid factor, antinuclear, thyroglobulin, thyroid microsomal, gastric parietal, mitochondrial, smooth muscle, and reticulin antibodies. These were detected using the standard indirect immunofluorescent techniques used routinely by the department of immunology, Newcastle General Hospital.

Spearman rank correlation coefficients were calculated for titres of proteus antibodies corresponding to the titres of autoantibodies and antibodies to viruses in the same serum sample. The serum samples were then divided into those samples with a $\mathrm{C}$ reactive protein concentration greater than $10 \mathrm{mg} / \mathrm{l}$ ('active RA') and those with a $C$ reactive protein concentration less than this value ('inactive RA'). Differences in titres of antibodies in the 'active' and 'inactive' RA groups were calculated for each autoantibody and antibody to viruses, and compared with any differences for the proteus antibodies in the same samples. All statistical tests were performed using the Statistical Package for the Social Sciences $\mathrm{x}$ (SPSS $\mathrm{x}$ ).

\section{Results}

One hundred and forty six samples were available for determining autoantibodies and proteus antibodies, and in 52 of these antibodies to viruses were also determined. Table 1 gives the Spearman rank correlation coefficients between proteus antibodies and autoantibodies and antibodies to viruses. The only significant correlation with proteus antibodies was for mitochondrial antibodies, where a significant inverse correlation was seen-that is, the higher

Table 1 Spearman rank correlation coefficients between proteus antibodies and various autoantibodies and antibodies to viruses

\begin{tabular}{lrl}
\hline Antibody & rValue & pValue \\
\hline Autoantibodies (n=146) & & \\
Rheumatoid factor & 0.02 & 0.39 \\
Antinuclear & $0 \cdot 11$ & 0.09 \\
Thyroglobulin & $0 \cdot 12$ & 0.08 \\
Thyroid microsomal & 0.03 & 0.36 \\
Parietal cell & 0.05 & $0 \cdot 28$ \\
Mitochondrial & -0.16 & 0.03 \\
Smooth muscle & 0.08 & $0 \cdot 16$ \\
Reticulin & 0.00 & 0.94 \\
Antibodies to viruses $(\mathrm{n}=52)$ & & \\
Influenza A & $0 \cdot 14$ & $0 \cdot 16$ \\
Adenovirus & $0 \cdot 15$ & $0 \cdot 15$ \\
Rubella & $0 \cdot 12$ & $0 \cdot 19$ \\
Parvovirus & 0.06 & 0.33 \\
\hline
\end{tabular}


Table 2 Median (maximum) titres of autoantibodies in patients with active $(C$ reactive protein $>10 \mathrm{mg} / \mathrm{l}$ ) and inactive rheumatoid arthritis $(R A)$

\begin{tabular}{|c|c|c|c|}
\hline \multirow[t]{2}{*}{ Autoantibody } & \multicolumn{2}{|c|}{ Median titre } & \multirow{2}{*}{$\begin{array}{l}\text { p Value } \\
\text { (Mann-Whitney } \\
\text { U test })\end{array}$} \\
\hline & $\begin{array}{l}\text { Active } R A \\
(n=83)\end{array}$ & $\begin{array}{l}\text { Inactive } R A \\
(n=63)\end{array}$ & \\
\hline Rheumatoid factor & $\begin{array}{l}1 / 80 \\
(>1 / 640)\end{array}$ & $\begin{array}{l}1 / 40 \\
(>1 / 640)\end{array}$ & $0 \cdot 11$ \\
\hline Antinuclear & $\begin{array}{l}1 / 10 \\
(1 / 320)\end{array}$ & $\begin{array}{l}1 / 10 \\
(1 / 640)\end{array}$ & $0 \cdot 08$ \\
\hline Thyroglobulin & $\begin{array}{l}0 \\
(1 / 1600)\end{array}$ & $\begin{array}{l}0 \\
(1 / 200)\end{array}$ & $0 \cdot 72$ \\
\hline Thyroid microsomal & $(>1 / 1600)$ & $(>1 / 1600)$ & 0.85 \\
\hline Parietal cell ${ }^{*}$ & $\begin{array}{l}0 \\
(+)\end{array}$ & $\begin{array}{l}0 \\
(++)\end{array}$ & 0.47 \\
\hline Mitochondrial & $\begin{array}{l}0 \\
(0)\end{array}$ & $\begin{array}{l}0 \\
(1 / 2560)\end{array}$ & $0 \cdot 10$ \\
\hline Smooth muscle & $\begin{array}{l}0 \\
(1 / 40)\end{array}$ & $\begin{array}{l}0 \\
(1 / 160)\end{array}$ & 0.85 \\
\hline Reticulin & 0 & $\begin{array}{l}0 \\
(0)\end{array}$ & 1.00 \\
\hline Proteus & $\begin{array}{l}1 / 40 \\
(1 / 640)\end{array}$ & $\begin{array}{l}1 / 20 \\
(1 / 160)\end{array}$ & $<0.0001$ \\
\hline
\end{tabular}

${ }^{*}$ Parietal cell antibodies are reported as positive $(+)$ and strongly positive $(++) \cdot \chi^{2}$ for this variable was $\mathrm{p}>0.05$.

Table 3 Median (maximum) titres of antibodies to viruses in patients with active $(C$ reactive protein $>10 \mathrm{mg} / \mathrm{l})$ and inactive rheumatoid arthritis $(R A)$

\begin{tabular}{|c|c|c|c|}
\hline \multirow[t]{2}{*}{ Antibody to virus } & \multicolumn{2}{|l|}{ Median titre } & \multirow{2}{*}{$\begin{array}{l}p \text { Value } \\
\text { (Mann-Whitney } \\
\text { U test })\end{array}$} \\
\hline & $\begin{array}{l}\text { Active } R A \\
(n=22)\end{array}$ & $\begin{array}{l}\text { Inactive } R A \\
(n=30)\end{array}$ & \\
\hline Influenza A & $\begin{array}{l}1 / 20 \\
(1 / 80)\end{array}$ & $\begin{array}{l}1 / 20 \\
(1 / 80)\end{array}$ & $0 \cdot 85$ \\
\hline Adenovirus & $\begin{array}{l}1 / 10 \\
(1 / 80)\end{array}$ & $\begin{array}{l}1 / 10 \\
(1 / 40)\end{array}$ & $0 \cdot 73$ \\
\hline Rubella & $\begin{array}{l}1 / 16 \\
(1 / 256)\end{array}$ & $\begin{array}{l}1 / 16 \\
(1 / 64)\end{array}$ & $0 \cdot 06$ \\
\hline Parvovirus $^{*}$ & $\begin{array}{l}++ \\
(++)\end{array}$ & $\begin{array}{l}++ \\
(++)\end{array}$ & $0 \cdot 17$ \\
\hline Proteus & $\begin{array}{l}1 / 40 \\
(1 / 640)\end{array}$ & $\begin{array}{l}1 / 10 \\
(1 / 160)\end{array}$ & $<0.0025$ \\
\hline
\end{tabular}

${ }^{*}$ Parvovirus antibodies are reported as equivocal $(+)$ and positive $(++) \cdot \chi^{2}$ for this variable was $\mathrm{p}>0.05$. increased proteus antibodies in active RA is not shared by the autoantibodies or the antibodies to viruses that were tested. In combination with the lack of a significant positive correlation with any of the other antibodies in this study, this suggests that the proteus antibody response may be specific in RA. The phenomenon appears to be organism specific in that this study and the work of Ebringer and coworkers on other responses to antibodies to bacteria in patients with $\mathrm{RA}^{4} 5$ have not shown any other significant increases in patients with active RA. Whether this phenomenon is disease specific is debatable, as Rogers et al found that although patients with RA had the highest levels of proteus antibodies, patients with coeliac disease had levels intermediate between those of the patients with RA and patients with other inflammatory diseases. ${ }^{2}$ Murphy et al did not find any difference between patients with RA and those with ankylosing spondylitis, ${ }^{9}$ which contradicts the earlier work of Ebringer et al. ${ }^{1}$

Future work needs to determine whether proteus antigen can be detected in patients with RA. A study by Wilson et al suggested that proteus could be isolated in the urine of patients with RA more often than in controls. ${ }^{10}$ Our own preliminary study did not find this. ${ }^{11}$ Studies also need to determine the antigen on the surface of proteus to which the antibody is directed. Work on patients with recent onset RA needs to address whether or not the antibody response is present, and if so, the class of antibody produced in the early phases of the disease. This work was funded by the Arthritis and Rheumatism Council.
We thank Professor C R Madeley and the laboratory staff, department of virology, Royal Victoria Infirmary, Newcastle department of virology, Royal Victoria Infirmary, Newcastle
upon Tyne for the adenovirus and influenza titres, Dr A Codd at upon Tyne for the adenovirus and influenza titres, Dr A Codd at
the department of microbiology, Newcastle General Hospital for the department of microbiology, Newcastle General Hospital for
the rubella titres, Drs K Brown, B Cohen, and M Buckley at the rubella titres, Drs K Brown, B Cohen, and M Buckley at
Central Public Health Laboratory, Colindale for the parvovirus titres, and Dr A Fay, department of immunology, Newcastle General Hospital, for the autoantibody screens. with autoantibodies reached significance.

The second analysis addressed the possibility that autoantibodies and antibodies to viruses might be higher during active phases of the disease. For the autoantibodies, 83 patients had active disease (C reactive protein $>10 \mathrm{mg} / \mathrm{l}$ ) and 63 did not. Table 2 gives the titres for each antibody in the groups with active and inactive RA. No autoantibody was significantly higher in the active compared with the inactive group. Only antinuclear antibodies had a trend in this direction ( $p=0.08$, Mann-Whitney $U$ test). For the same 146 samples the higher proteus antibodies in the active group were highly significant $(\mathrm{p}<0.0001)$, with a significant correlation between proteus antibodies and $\mathrm{C}$ reactive protein $(r=0.46, p<0.001)$. A similar pattern of results was seen for the antibodies to viruses, with only rubella showing a trend towards higher titres in the active RA group ( $p=0.06$, table 3 ). For the same 52 samples, the proteus antibodies were again significantly higher in the active group $(p=0.0025)$, and there was a significant correlation between proteus antibodies and $C$ reactive protein $(r=0.52, p<0.001)$.

\section{Discussion}

These results suggest that the phenomenon of
1 Ebringer A, Ptaszynska T, Corbett M, et al. Antibodies to Proteus mirabilis in rheumatoid arthritis. Lancet 1985; ii Proteus

2 Rogers $\dot{P}$, Hassan J, Bresnihan B, Feighery C, Whelan A. Antibodies to Proteus in rheumatoid arthritis. $B r \bar{J}$ Rheumatol 1988; 27 (suppl 2): 90-4.

3 Deighton C M, Gray J W, Bint A J, Walker D J. Anti-proteus antibodies in rheumatoid arthritis same-sexed sibships. $\mathrm{Br}$

4 Ebringer A, Cox N L, Abuljadayel I, et al. Klebsiella antibodies in ankylosing spondylitis and Proteus antibodies in rheumatoid arthritis. Br $\mathcal{O}$ Rheumatol 1988; 27 (suppl 2): 72-85.

5 Ebringer A, Khalafpour S, Wilson C. Rheumatoid arthritis and Proteus: a possible aetiological association. Rheumatol Int 1989; 9: 223-8.

6 Deighton C M, Wentzel J, Cavanagh G, Roberts D F, Walker D J. Contribution of inherited factors to rheumatoid arthritis. Ann Rheum Dis 1992; 51: 182-5.

7 Ropes M W, Bennett G A, Cobb S, Jacox R, Jessar R A Rheum Dis 1958; 9: 175-6.

8 Deighton C M, Madeley C R, Walker D J. Anti-viral antibodies in rheumatoid arthritis same-sexed sibships [letter]. $\mathrm{Br} \mathcal{F}$ Rheumatol 1992; 31: 357-8.

9 Murphy E A, Mowat L, Sturrock R D. Antibodies to proteus in rheumatoid arthritis [letter]. $\mathrm{Br} \mathcal{F}$ Rheumatol 1991; 30: 390.

10 Wilson $C$, Corbett $M$, Ebringer A. Increased isolation of Proteus mirabilis species from rheumatoid arthritis patients compared to osteoarthritis patients and healthy controls [abstract]. Br $\mathcal{f}$ Rheumatol 1990; 29 (suppl 2): 99. Failure to isolate Proteus in the urine of rheumatoid arthritis patients more frequently than controls [abstract]. Br F Rheumatol 1991; 30: (suppl 2): 3. f Rheumatol 1992; 31: 241-5. Revision of diagnostic criteria for rheumatoid arthritis. Bull

11 McDonagh J, Gray J, Deighton C M, Sykes H, Walker D J. 